AUTHOR:

Cheryl Le Roux

AFFILIATION:

College of Education, Department of

Educational Foundations

University of South Africa

CORRESPONDENCE TO:

Irouxcs@unisa.ac.za

DATES:

Published: 14 September 2020

HOW TO CITE THIS ARTICLE:

Le Roux, C.S., 2020. Teaching

towards Christian environmental

stewardship - to what extent are

the Tbilisi Declaration objectives for

environmental education relevant?

KOERS - Bulletin for Christian

Scholarship, 85(1). Available at: https://

doi.org/10.19108/KOERS.85.1.2422

COPYRIGHT:

(c) 2020. The Author(s)

Published under the Creative

Commons Attribution License.

\section{Teaching towards Christian environmental stewardship - to what extent are the Tbilisi Declaration objectives for environmental education relevant?}

\begin{abstract}
Christians, as believers and followers of God's word, are biblically appointed as stewards of the created biophysical world (Genesis, 1:26-31; Genesis, 2:15). This task is accomplished through practising environmental stewardship (ES). In a secular context, care for the environment is promoted through environmental education (EE). The Tbilisi Declaration (1977) articulates specific goals, objectives and principles of EE which have been followed by environmental educators for decades. This study aimed to determine to what extent the Thilisi objectives of EE apply in the Christian context where EE is practised through educating towards ES. Research findings evidenced that apart from the five Tbilisi objectives, educating for ES employs an additional objective. This objective is the fostering of reverence for the environment which precedes the Tbilisi objective of cultivating environmental awareness. Reverence for God's creation underlies the Christian yearning to obey, honour and bring glory to God. In the Church, educating for ES consequently should be based foremost on nurturing reverence for God's creation. It is argued that ES will be more effective if reverence for creation is at the forefront.
\end{abstract}

Key words: Objectives of environmental education; environmental stewardship, Christian stewardship, reverence for creation

Onderrig jeens Christelike omgewingsrentmeesterskap - tot watter mate is die Tbilisi-verklaring se doelwitte vir omgewingsleer relevant?

\section{Opsomming}

Christene, as gelowiges en navolgers van God se Woord, is aangestel volgens die Bybel as rentmeesters van die geskepte biofisiese wêreld (Genesis 1:26-31; Genesis 2:15). Hierdie taak word uitgevoer deur die beoefening van omgewingsrentmeesterskap (ES). In 'n sekulêre konteks word omgewingsorg bevorder deur omgewingsleer (EE).

Die Thilisi-verklaring (1977) verwoord spesifieke mikpunte, doe/witte en beginsels van EE wat al dekades lank deur omgewingsopvoeders gevolg word. Hierdie studie se doel was om te bepaal tot watter mate die Tbilisi-doelwitte van EE in die Christelike konteks van toepassing is waar EE beoefen word met die onderrig vir ES. Bevindings uit navorsing dui daarop dat buiten die vyf Tbilisi-doe/witte, daar 'n addisionele doelwit is vir die onderrig vir ES. Hierdie doelwit is die bevordering van gesag vir die omgewing wat die Tbilisi-doelwitte vir die ontwikkeling van omgewingsbewustheid voorafgaan. Eerbied vir God se skepping lê die Christelike hunkering om God te gehoorsaam en ere aan God te betoon, ten grondslag aan. In die kerk moet die onderrig vir ES dus eerstens gebaseer wees op die kweking van eerbied vir God se skepping. Daar word geredeneer dat ES meer effektief sal wees indien eerbied vir die skepping op die voorgrond is

Sleutelwoorde: Doelwitte van omgewingsleer; omgewingsrentmeesterskap; Christelike rentmeesterskap; eerbied vir die skepping 


\section{Introduction}

The world's first intergovernmental conference on environmental education (EE) was organised by the United Nations Education, Scientific, and Cultural Organization (UNESCO) in cooperation with the United Nations Environment Programme (UNEP) in Tbilisi, Georgia (USSR) in October 1977. The Tbilisi Declaration noted the important role of education in the preservation and improvement of the world's environment and as such set out the goals, objectives and principles of EE at all levels and for all age groups within and outside of the formal education system (UNESCO, 1978:26-27).

For decades these goals, objectives and principles have been used by environmental educators in the process of planning, presenting and assessing EE programmes. It is subsequently accepted that if these goals and objectives are met and the principles are followed, the programme will be effective in achieving its purpose. According to the Tbilisi Declaration (UNESCO, 1978:26-27) the objectives of EE which are aligned with the goals of EE and underpin the principles are:

- $\quad$ acquiring an awareness of and sensitivity to the total environment and its allied problems

- $\quad$ gaining knowledge and a basic understanding of the environment and its associated problems

- developing attitudes and a set of values and feelings of concern for the environment

- $\quad$ learning skills for identifying and solving environmental problems

- $\quad$ providing opportunities for active participation in working toward the resolution of environmental problems

The study reported on in this article investigated the application of the Tbilisi objectives in relation to EE aimed to support and foster Christian environmental stewardship (ES) in the Uniting Reformed Church of Southern Africa (URCSA). The objectives of EE as presented in the Declaration were developed within a secular context and the research was undertaken to establish whether these objectives applied equally within a Christian faith-based context.

\section{Conceptual framework}

The Bible, as the inspired word of God, is the basis of the Christian's belief system and ethic for redemption and everyday living. The Bible is the revelation of God's plan and purpose for His creation and although the Bible deals primarily with the relationship between God and humankind and the way to salvation and eternal life, the Bible also presents principles that entreat the protection of the natural and biophysical world in a holistic manner (Bauckman, 2002:141; Esler, 1998:223-224; Horrell, Hunt \& Southgate, 2008:223-224). God specifically commands believers to tend His creation and not to abuse it (Genesis, 2:15). A foremost tenet of Christians' understanding of their place in the world is contained in Psalm 24 verse 1, which states: "The earth is the Lord's, and the fullness thereof; the world, and they that dwell therein." This sentiment is reiterated in 1 Corinthians 10:26. God's love thus explained extends not only to people, but also to the earth itself and to all its creatures - the entire biophysical world. The material world matters to God; He upholds, sustains it (Colossians, 1:17; Hebrews, 1:3) and reveals His supremacy to humankind through it (Psalms, 8:3, 4; Romans, 1:20). This principle forms the basis for believers' commitment to care for the earth: thereby to bring glory to God and witness to the world (Matthew, 5:16). Believers are required to live responsibly and to tread judiciously on the earth, to use its resources wisely and to nurture and protect it - in other words to act as responsible stewards for the environment as God commanded (cf. Genesis, 2:15).

From a scriptural perspective, Christians could be guiding the environmental agenda. 
However, if one considers the extreme environmental crisis confronting humankind at present, the Christian Church, given its substantial following of a probable 2,2 billion people of a world population of an estimated 7,4 billion people (Pascaline, 2016), seems to have failed to embody and practise the vision of responsible ES. The Church, according to Dorr (1991:123) and Hurley (2004), can make a major contribution to addressing the environmental crisis by developing, preaching and practising a holistic spirituality that promotes a partnership and custodial ethic towards the environment as scripturally mandated. Conradie and Field (2000:1), Clarke (2007) and James (2009) point out that the Church has an important role to play in raising environmental awareness and responsibility among its followers. In 1995, the Synod of the Dutch Reformed Church (DRC) in the Western Cape took a decision to make an urgent appeal to all members of the Synod to support the cause of environmental conservation in a responsible manner and in so doing to obey the scriptures, which teach humankind to rule - exercise custodial stewardship - over creation and preserve it (Western Cape Synod, 2000:106-109).

\section{A synopsis of concepts and assumptions underlying the study}

The Church, through its biblically mandated duty of care for the environment, should strive to raise awareness and responsible decision making and action taking regarding the environment among its followers. Apart from its imperative to provide spiritual guidance that leads to salvation, the Church should also engage with issues that relate to the biophysical world such as promoting the issue of environmental and social justice, environmental awareness and environmentally responsible attitudes and behaviour amongst congregants. This extensive task is accommodated by and accomplished through ES. However, to be good environmental stewards, individuals need to be sufficiently knowledgeable, have the right attitude and have the necessary skills to implement ways in which to actively engage in caring for the environment. These attributes can be achieved through EE.

\subsection{Environmental education}

Within the context of this study, the concept of EE has been defined as follows:

It is a process that seeks to develop the necessary awareness, concepts, ethics, values, skills and commitment to allow people to become environmentally literate in order to be pro-active in securing a healthy and properly functioning environment that is sustainable (Little, in SAAPPI, 1998:103).

It is therefore within the scope of the objectives of EE (as articulated at the Tbilisi Conference) to produce citizens who are aware of environmental concerns, who are knowledgeable about the environment and its associated problems, who exhibit pro-environmental behaviour and attitudes, who find ways of solving these problems, who acquire the relevant skills to address these problems, and who come up with strategies that could motivate people to work individually and collectively towards the solution of environmental problems.

\subsection{Environmental literacy}

The ultimate goal of EE is to produce a citizenry that is environmentally literate (Elder, 2003:15). Roth (Disinger \& Roth, 1992:7) defines EL as follows:

Environmental literacy is essentially the capacity to perceive and interpret the relative health of environmental systems and take appropriate action to maintain, restore, or improve the health of those systems. It tends to be defined in terms of observable behaviors through which people demonstrate in some recognizable form what they have learned: their knowledge of key concepts; the skills acquired; and their disposition, attitude or outlook toward issues. 
Described in this way, EL has a distinct link with the objectives of EE as presented in the Tbilisi Declaration and also addresses concepts like awareness, knowledge, skills, attitudes and action taking.

\subsection{Stewards and stewardship}

A steward is someone who takes responsibility for the care of something for someone else. Stewards are accountable for the degree of success of their stewardship and this success or lack thereof is assessed by determining the wellbeing of the entity of which stewardship is provided (Travis, Egger, Davies \& Mechbal, 2002).

In the biblical context, the characteristics of stewards are outlined by Paul who describes stewards as being required to be trustworthy, blameless, neither arrogant nor quicktempered, nor a drunkard nor violent nor greedy for money (1 Corinthians, 4:2). Stewards must love what is good, be self-controlled, upright, holy and disciplined. They should encourage others with the true teaching and show the error of those who are opposed to the truth (Titus, 1:7-9). Peter adds to these requirements of stewards pointing out that they should act as custodians, administrators or supervisors (1 Peter, 4:10).

\subsection{Christian stewardship}

Christian stewardship (CS) is the practice of systematic and proportionate giving of one's time, abilities and material possessions, based on the conviction that these are a trust from God to be used in His service for the benefit of all mankind in grateful acknowledgement of Christ's redeeming love (Gehman, 1970:906; John 3:16-17). CS is the Christian's way of life. Through practicing, CS believers are responsive to God's calling and thereby bring honour and glory to God (Gray, 2001).

\subsection{Environmental stewardship}

In Genesis 2 verse 15, humankind finds itself the appointed steward or custodian of God's created biophysical world. God gave humans authority over nature not as owner or exploiter, but as stewards who share the creative care of the Creator (Wellman, 2015). Esler (1998:219) indicates that an environmental steward is:

- $\quad$ responsible for the conservation of the land, so that it will not go to waste

- $\quad$ responsible for its improvement, so that it becomes more productive

- $\quad$ responsible for the care of fellow creatures, the non-human inhabitants

The Bible indicates that Christians have a divine mandate of ES (Luke, 16:3, 4) for the human race has been placed in charge of God's creation and everything has been placed under his authority (Psalm, 8:5-6).

\section{Research problem statement}

The action of Christians' caring for the environment as a demonstration of their biblical mandate is understood as an ES duty. To equip an individual to carry out these stewardship duties, the underlying assumption is that the individual should be environmentally literate - a disposition which is acquired through EE. Generally, EE programmes are structured in a way that bears in mind the objectives of EE as articulated in the Tbilisi Declaration, namely that the programme should cultivate awareness, develop knowledge and skills, create proenvironmental attitudes and provide for active participation in environmental endeavours.

This study specifically attempted to establish whether the Tbilisi objectives of EE were equally applicable to EE in a Christian context as they are in a secular context. The research problem could thus be stated as: To what extent are the objectives of EE as articulated in the Tbilisi Declaration relevant for EE through ES in a Christian biblical context? 


\section{Research context and method}

The research reported in this article was part of a mixed methods research project undertaken amongst ministers, lecturers, final-year seminary students and church elders in the URCSA. The study followed a case study design. The purpose of the project as a whole was to examine the status and level of understanding of EL and ES in selected URCSA churches and seminaries. In total, three hundred and sixty ministers, twenty lecturers, twenty-three final-year BTh. students and fifteen church elders participated in the study. The data for the study was collected through a questionnaire, which was quantitatively analysed. Individual and focus group interviews were also conducted of which the data was analysed following Tesche's model for qualitative data analysis (Tesche, 1990).

The faculty brochures for the BTh. degree programme for the two participating universities provided the curriculum as well as module outlines. The curricula of both universities were similar. The curricula comprise compulsory and elective modules. One of the elective modules at one of the institutions specifically addresses the environment and care for the environment from a biblical perspective. This module can be regarded as a typical EE module. However, since this is an elective module, students who do not choose this module from the list will ultimately leave the university without having interacted with a module that specifically provides education for the environment.

The research reported on in this article arises from the findings from the individual and focus group interviews conducted with ministers, lecturers and students. A total of fiftyeight ministers and seven lecturers who are also ministers of the URCSA were individually interviewed using a semi-structured interview schedule. Nine final-year seminary students were interviewed individually and two focus group interviews with seven final-year students each were conducted. Interview schedules designed specifically for this group of respondents guided the interview process for each of these data collection strategies. The interviews were recorded and transcribed and the ensuing data was qualitatively analysed. Respondents were from Gauteng, Limpopo, North West and the Western Cape and were selected through convenience sampling.

A variety of aspects related to ES were explored during the interviews. These topics included the status of ES as a dimension of respondents' CS duty, the degree of ES evident in the Church and seminary training programmes, the level of environmental awareness and EL amongst respondents and whether respondents had received EE either in-service or preservice.

\section{Research findings and discussion}

Interviewees were asked whether they had received any form of EE during their careers as ministers and in their training as students and to elaborate on the scope and nature of this training. The responses are discussed below.

\subsection{Students' exposure to and perception of EE}

Students felt strongly that it is essential that teaching about the environment should be included or form an integral part of their training, given that Christians are biblically mandated to care for the earth. Students are aware that CS, which is synonymous with Christian living, also implies ES. Given the current environmental crisis and their responsibility as aspirant ministers to address these issues in their future congregations, the general opinion was that they are not being adequately prepared for this task. Students are acutely aware of the environmental crisis, but teachings about this and how Christians should deal with the matter specifically is lacking from the curriculum. The biblical justification for ES is adequately covered in the curriculum; however, students believed that they lacked practical knowledge of how to conceptualise and apply ES effectively. 
Of the twenty-three final-year students who were interviewed, only six had studied the elective semester module, God, Creation and the Environment which discusses environmental issues from a biblical perspective. In this module, students are familiarised with the causes of the global environmental crisis and the effect this has on humanity and the planet in general. This module promotes an environmentally friendly lifestyle based on biblical principles. One of the purposes of the module is to enable students to argue and debate environmental issues from a biblical perspective. Another feature of the module is the emphasis on being able to initiate, develop, facilitate and participate in community development programmes and projects aimed at improving environmental conditions. This could be described as "ES in action".

The compulsory Ethics and Life or Systematic Theology and Ethics module in the BTh. programme does specifically cover aspects of ES. In this module, the connection between what Christians believe and how they conduct their lives is emphasised. Other modules like Bible and Biblical background, Old Testament Studies (in which concern and care for creation and humanity was highlighted), and New Testament Studies, entrenches the concepts of CS, ES and EL although not directly teaching for EL. Students pointed out that the BTh. programme specifically focuses on how faith and religion influence the way one lives and how God's supremacy is revealed through the scriptures commanding believers' faith, reverence and obedience to carry out their duty of CS and ES.

It is challenging to accurately gauge to what extent the objectives of EE are entrenched in the modules since none of the modules - apart from the elective module referred to - is specifically an EE module. However, it is clear that in the EE module attention is given to the following objectives:

- $\quad$ raising awareness of the condition of the environment and the consequence of human interaction on the environment

- $\quad$ providing knowledge about the environmental condition

- $\quad$ teaching skills that advance knowing how to deal with environmental problems

- cultivating attitudes of respect and value for the environment

- $\quad$ enabling participation in actions aimed at improving environmental conditions

This module indeed encompasses within it the Tbilisi objectives of EE in educating students towards ES.

The compulsory modules in which ES is dealt with addresses the following objectives:

- $\quad$ raising awareness of the duty of care towards the environment as well as drawing attention to the complexity and vastness of the concept environment from a biblical perspective

- $\quad$ providing knowledge about the environment and its interconnectedness from a biblical perspective in order to facilitate ES

- developing skills regarding how the Christian community should care for the environment through practicing their ES duty, following the biblical principles of caring for the environment and conducting their lives in accordance with biblical tenets

- actively engaging in ES within the Church and broader community

- cultivating an attitude of gratitude and admiration in relation to the magnificence of God's creation 
It is evident that the attributes of raising awareness of Christians' duty of ES, providing knowledge and skills from a biblical perspective about the environment, developing an attitude of wonder for God's creation and awareness of the need to actively participate in ES are encompassed and entrenched in the curriculum.

\subsection{Ministers' exposure to and perception of EE}

Of the sixty-five ministers and lecturers who were interviewed, only fifteen indicated that they had been exposed to EE programmes - generally as part of Adult Basic Education Training programmes which they had engaged in of their own accord. These programmes had not been provided as part of an in-service programme and it was found that no inservice EE had been provided by the Church for these ministers.

Despite not having received formal EE during their training (the ministers and lecturers were all of a mature age) which would have enhanced their EL and led to a more informed understanding of how to practise and demonstrate ES within the Church and the broader community, ministers concurred that as Christians, they and the Church have a moral, biblically founded obligation to care for creation as part of their CS duty. Interviewees were unanimous that ES is a crucial dimension of their responsibilities in the Church. However, environmental issues are not adequately addressed in the Church or the community at present. One of the ministers commented:

This [the lack of focus on ES] is a weak spot in the Church and it is our duty as ministers to address it. We cannot ignore it.

Another minister, who agreed that insufficient attention is given to ES in the ministry, explained that:

If we neglect the environment, we are in danger of being indifferent to our commitment to God. The Bible tells us that we are stewards of the earth and we have to care for the earth. We are disobeying God if we neglect looking after the earth.

Another response was:

Taking care of the environment and creation is a must to all of us as citizens of our countries and inhabitants of the planet. Protecting the environment is investing in our own survival and the survival of our children and the generations to come.

However, he questioned the process of doing this:

How do we inculcate the importance of ES within our congregations?

Another interviewee for whom the lack of ES in the Church was also a concern commented that:

We do not perceive nature as part of our ministry. We only concentrate on winning souls and raising funds for the congregations.

Interviewees emphasised that believers need more than a mere ethic of environmental care. It was suggested that ES education from a Christian perspective should embody respect for the environment, that is, awareness of the intrinsic value of the environment and an ethic or attitude that promotes care for, protection and conservation of the environment. It was argued that this stance should increasingly become, by choice, an intrinsic dimension of Christian living as a way of bringing glory to God, which is a profound Christian calling. As a Christian, one is admonished to become more Christ-like. This means that Christians are to live in harmony with each other and the natural environment, since the teachings of Jesus in the Gospels portray a harmonious relationship between God, humanity and nature, a 
relationship which human neglect, avarice and materialism will destroy. Christians are to live in accord with nature and use it judiciously. The underlying principle in relation to ES education (or EE), is that, in order to do this, Christians need to have a clear understanding and knowledge of the environment, how it functions and how humans impact on the environment. They are also required to be aware of and have respect for the underlying value of the environment. However, since Christians believe that God "fills heaven and earth" (Jeremiah, 23:23-24) and that God is the "God of all flesh" (Jeremiah, 32:27), a deepseated awe for God and His magnificence is an undisputed realisation unique to Christians. The Christian believer cannot but be enthralled by the omnipotence of God as he comes to learn more about God's creation as he endeavours to practise ES in obedience to God's commandments. The manner in which people use, respect and interact with the environment is consequently a manifestation of the depth of their relationship with God.

Several interviewees mentioned examples of where the Bible is explicit in maintaining that those who adversely impact creation will need to bear the consequences of their indiscretions and are subject to the judgment of God (cf. Leviticus, 26 \& Deuteronomy, 28). Ministers cited various illustrations such as rain being withheld (Jeremiah, 3:3), the land being made desolate (Jeremiah, 12:10-11), the land being polluted (Isaiah, 24:5), and species being destroyed (Hosea, 4:3) when people don't attend to God's commandments.

Reviewing the feedback provided by practising ministers of URCSA, the objectives of ES education in a Christian context are to:

- $\quad$ promote respect for the environment as an exemplification of God's caring attitude towards creation

- $\quad$ raise awareness of the immensity of God's creation and the scope of the ES duty

- develop a pro-environmental behaviour through promoting an ethic or attitude of responsibility towards the environment

- $\quad$ enhance an appreciation for, knowledge of and accurate understanding of the intrinsic value of the environment and the relationship and interaction between humankind and the biophysical world

- teach responsible decision-making and action-taking skills in respect of protecting, preserving and caring for creation

- $\quad$ acknowledge human accountability for the way the environment is used and treated

- draw attention to the fact that ES education is mandated scripturally

However, fundamental to the above is the acknowledgment of the limitlessness of creation and the respect and wonder that this has as a consequence for the Christian believer.

\section{Conclusions and recommendations}

Interviewees concurred that a Gospel proclaiming salvation for humans without placing this salvation within the broader context of God's love and concern for the whole of creation is short of the "full" Gospel. Caring for the "souls" of people without caring for their total wellbeing (which includes the environmental in which they live) witnesses to a "dead" faith (cf. James, 2:14-17; 1 John, 3:16-18). ES of the created world is undisputedly recognised in the scriptures.

Humankind, being conferred with the responsibility of looking after creation and having the ability to reason, is required to make informed decisions based on knowledge and experience on how best to actively engage in the protection, care and preservation of the environment. Christian believers have a biblically mandated moral obligation towards the 
biophysical environment. They have in their power, but also their responsibility, to see to it that the environment is not degraded, but safeguarded from exploitation. Included in and underlying this observation are the five objectives of EE as contained in the Tbilisi Declaration: awareness, knowledge, skills, attitude and active participation. In addition, it can be posited that the manner in which Christians use and interact with the environment shows the depth of their relationship with God and their understanding of and respect for His sovereignty.

Developing and practising ES is linked to individuals' EL which is achieved through education. EL presupposes awareness and knowledge of the environment and its interrelatedness, a pro-environmental attitude and the intellectual and practical skills needed to incorporate appropriate environmental considerations into daily decisions. EL also presupposes the ability and desire to engage in individual and collective pro-environmental activities.

The research evidenced that in the Church the practice of ES is akin to EE as practised in a secular context. An analysis of the process of establishing the tenet of ES evidenced that both among practicing ministers of the URCSA and seminary students, education was crucial. In the course of this process of educating towards ES, all five objectives of EE as articulated in the Tbilisi Declaration were manifest: raising awareness, developing knowledge, gaining appropriate skills, establishing a conducive attitude and promoting active engagement. However, within the Christian community, when compassion, reverence and awe are present, individuals are more effectively sensitised to the needs of and their duty of care towards the environment. The basis of a Christian's EL achieved through education starts not with awareness of the environment, but with awe and amazement for the beauty, intricacy, sophistication and vastness of God's creation. Consequently, it is recommended that when education towards ES is undertaken within the Church, in addition to the five Tbilisi objectives of $\mathrm{EE}$, the objective of fostering reverence for the magnitude of God's creation precedes the secular objectives of awareness, knowledge, skills, attitudes and participation. Reverence for God's creation underlies the Christian yearning to honour and bring glory to God. Furthermore, the seminary curricula need to be explicitly structured so that dedicated training in ES as biblically mandated is infused in students' training programmes. Through such compulsory training in ES, ministers-in-training will be better equipped to practise ES within their congregations and be better prepared to inspire ES within their communities.

\section{Acknowledgement}

The contribution of Rev Dr RD Tshenye (URCSA) to the research of this article is gratefully acknowledged.

\section{References}

BAUCKMAN, R.J. 2002. God and the crisis of freedom: Biblical and contemporary perspectives. Louisville: John Knox Berry.

BIBLE. 1982. Good News Bible. Today's English Version. Great Britain: William Collins Sons \& Co. Ltd.

CLARKE, G. 2007. Agents of transformation? Donors, FBOs and international development. Third World Quarterly, 28(1):77-96.

CONRADIE, E. \& FIELD, D. (2000). A rainbow over land. Pretoria: Salty Print.

DISINGER, J.F. \& ROTH, C.E. 1992. Environmental Literacy. http://www.ericdigests.org/1992-1/literacy. htm Date of access 21 May 2012.

DORR, D. 1991. The Social Justice Agenda. New York: Orbis Books.

ELDER, J.L. 2003. A field guide to environmental literacy: making strategic investments in environmental education. www.naaee.org Date of access 22 July 2012.

ESLER, P.F. 1998. Christianity for the twenty-first century. Edinburgh: Clark.

GEHMAN, H.S. 1970. The New Westminster Dictionary of the Bible. Philadelphia: Westminster Press. 
GRAY, P.C.L. 2001. Christian Stewardship: What God Expects from Us. Lay Witness. http://www. catholiceducation.org/en/culture/environment/christian-stewardship-what-god-expects-from-us. html Date of access 23 March 2017.

HORRELL, D.G, HUNT, C. \& SOUTHGATE, C. 2008. Appeals to the Bible in ecotheology and environmental ethics: a typology of hermeneutical stances. Studies in Christian Ethics, 21:219-238. https://doi. org/10.1177/0953946808094343.

HURLEY, D. 2004. How beautiful is God's creation? http://www.neccsa.org.za/documents/DocumentsKZN-Pastoral.php Date of access 12 October 2010.

JAMES, R. 2009. Advantages and challenges for Christian Churches and organizations for doing development work. HTTP://WWW.BISTANDSNEMNDA.NO/NEWSREAD/READIMAGE. ASPX?WCI=GETBYLD\&IMAGEID=59\&DOCID=10027 Date of access 12 October 2010.

MERRITT, J. MOHLER, A. \& BEISNER, C. 2010. How concerned Christians should be about environmental care. http://www.christianitytoday.com/ct/2010/june/26.46.html?start=1 Date of access 22 March 2017.

PASCALINE M. 2016. How many Christians are there in the world? International Business Times, December 12, 2016. https://www.yahoo.com/news/many-christians-world-113630753.html Date of access 24 March 2017.

SAAPI. 1998. International, Best of Both Worlds Conference. Conference proceedings. Midrand: Kagiso Publishers.

TESCHE, R. 1990. Qualitative research. New York: Falmer Press.

TRAVIS, P., EGGER, D., DAVIES, P. \& MECHBAL, A. 2002. Towards better stewardship: Concepts and critical issues. http://www.who.int/healthinfo/paper48.pdf Date of access 10 January 2010.

UNESCO. 1978. Tbilisi Declaration. http://unesdoc.unesco.org/images/0003/000327/032763eo.pdf Date of access 12 March 2017.

WELLMAN, J. 2015. Taking care of the earth. http://www.patheos.com/blogs/christiancrier/2015/06/23/ top-7-bible-verses-about-taking-care-of-the-earth/ Date of access 20 March 2017.

WESTERN CAPE SYNOD. 2000. Resolutions of the Western Cape Synod of the Dutch Reformed Church. Cape Town: NGK. 